\title{
William Harvey and the Circulation of the Blood
}

\section{JOHN MARTIN and RICHARD EIMAS}

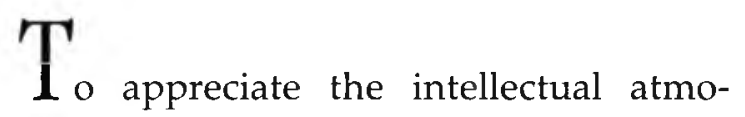

sphere in which William Harvey (1578-1657) worked one needs to review briefly the preceding centuries, and particularly the 1400 years back to the time of Galen (Claudius Galen of Pergamon, 130-200 A.D.). As in any long period of time, the general progress of man was forward, but it seems that in those centuries after Galen it was a matter of two short steps forward and one long step backward. Continuous wars, the rise of strong and rival political states, the domineering power of the Church of Rome, religious schism, the profound effects of Islam, great pestilences such as bubonic plague and syphilis, all accompanied by the miserable living conditions of the masses, were hardly conducive to anything but the crudest aspects of biological science.

The invention of the printing press produced a voluminous medical literature before Harvey, particularly in anatomy, less so in anything truly physiological. Anatomy, or structure, had to precede physiology, or action. But from the earliest times the distinction was incomplete, the two being mixed in an amalgam of "science," along with superstition, astrology, theology, teleological reasoning, and, too often, plain guesswork. Today we limit our study of medical history mainly to events in the Western world, but it would be unrealistic not to think that a great body of biological information was available in the ancient civilizations of such countries as China and India. It is customary to begin modern medical history with Hippocrates (460-370 B.C.), Aristotle (384-322 B.C.), various members of the Alexan- 
drian School, as Erasistratus and Herophilus (ca. 350 B.C.), and so on through the waning classical Greek period to Galen.

A consideration of the state of medical science leading up to the time of Harvey conveniently begins with Galen, for Galen, in his voluminous writings, summarized all that had gone before him, added his own original work which was phenomenally extensive for one man, and expressed himself so authoritatively and logically that he remained for the most part unquestioned for fourteen centuries. Indeed, with Galen as his mentor, the scholar needed and accepted but little more; with the various works of the physician-botanist Dioscorides (ca. 50 A.D.) and the Canon of Avicenna (980-1037), he was fully armed. There was no reason to question these truths. The Christian, Hebrew, and Moslem faiths all frowned upon or prohibited human dissection; medical writings consisted mainly of translations of the classics or endless commentaries on and restatements of such authorities as Galen and Avicenna, with the result that there was practically no advancement of the medical arts. Galen's authority, particularly, was not to be questioned. Galen, with his facile, ingenuous answers for all problems, congealed medical progress all through the Middle Ages until the first cracks in his laws appeared during the early stirrings of the Renaissance.

The Anathomia of Mondino dei Luzzi of Bologna (1275?-1326), written in 1316 and first printed in 1476, was little more than a student's handbook, purely Galenical, entirely without originality, but it represented the first return after centuries to the dissection of the human body for anatomical study. In spite of the fact that Mondino saw structures in the cadaver clearly displayed by his prosectors (anatomists), he doggedly, and no doubt in reverence for "that Prince of Physicians," Galen, described what he saw strictly the way Galen had described it centuries previously. It was a popular book and went through many editions but it contributed nothing to anatomy, physiology, or the nature of the cardiovascular system. Nevertheless, it was a beginning. The author, if not actually doing the 
dissection himself, did at least personally observe human dissection, however much in error his deductions were.

In an overview of the rapidly changing and increasing biological knowledge of the Renaissance, here considered as the period from Mondino through Harvey, many notable names are encountered. Most of these men were primarily anatomists, though they usually also practiced some clinical medicine and surgery, and their works contain fragmentary bits of physiology, all too often erroneous. But out of this period there arose more order in anatomical nomenclature, a gradual weaning away from the philosophy of the ancients, and a growing disdain for the restrictions of the Church. The practical matter of how the body functions began to be considered. The hands-on method of dissection by the teacher himself grew popular, and vivisection was used increasingly so that some of the grosser facts of physiology were revealed. These Renaissance doctors became bolder each decade with their denial of Galen, though Galen continued to have his loyal supporters, even among the best educated, well into the eighteenth century. Certain of these men and their published works made a strong impression on William Harvey, though the method of investigation Harvey used was his own. Credit is due to some of the more prominent names during this crucial period of the history of medicine: Leonardo da Vinci (14521519), Jacopo Berengario da Carpi (1470-1530), Andreas Cesalpino (1519-1559), Michael Servetus (1511-1553); the six great figures comprising the "Vesalian School" at the zenith of Padua's renown as a center for medical study: Andreas Vesalius (1514-1564), Realdo Colombo (1516-1559), Gabriele Fallopio (1523-1562), Hieronymus Fabricius ab Aquapendente (15331619), Giulio Casserio (1561-1616), and Adriaan van der Spiegel (1568-1625). With Spiegel anatomy peaked; it had been refined about as much as possible without the aid of the microscope and more sophisticated methods of study. Spiegel was interested in comparative anatomy and the action of the musculature. Harvey, for two years the pupil of Fabricius, originated an 
experimental approach to functional anatomy, that is, physiology, and after him in rapid succession came such men as Lower, Malpighi, and Borelli.

If one understands the Galenic rules for anatomy and physiology under which the scientific community labored, one can understand how difficult it was to refute those rules, how daring, actually risky, for those rules, reverently frozen for centuries, were cleverly written and left no open ends. According to Galen, and indeed in large part all the way back to Aristotle, there was an overall Life Force, an Anima, a Pneuma, contained everywhere in the air, inhaled with the air, and necessary for all animal life. The life-giving blood, present visibly in the blood vessels, ebbed and flowed, back and forth, with varying speeds throughout the body, being continuously manufactured by the liver from the nutriments brought to the liver via the portal veins from the gastrointestinal tract. In the liver the nutriments were transformed into materials usable by the body and for creating blood. In the liver this continuouslyrenewed supply of blood was enriched by the Natural Spirit. The blood passed from the liver via the inferior vena cava to the right side of the heart, and from there part of it went through the pulmonary artery to the lungs, and part of it passed directly through pores in the septum of the heart into the left ventricle. In the lungs the blood nourished the parenchyma of the lungs and cooled the blood of the excessive heat which the heart had generated. The inhaled air absorbed the proper content of Pneuma, that essential Force which had been named but never really defined since ancient times. It was the basis of life, the soul, an entity apart from the body in origin and yet a part of the body. In short, it was a concept difficult to understand. Blood, descending from the brain, brought with it the Animal spirit which had been formed there, and this blood reached the right side of the heart through the superior vena cava. In the lungs the terminations of the pulmonary artery made fine connections with the terminals of the pulmonary vein. Blood in the lungs returned to the left side of the heart through the pulmonary vein, there mixing with the blood which had come 
directly through the septal wall from the right ventricle. Vital Spirit, formed by the heart, mixed with this blood, already containing Pneuma and Natural and Animal Spirit. Now the blood, flowing throughout the body, expelled sooty vapors and air through the pores of the skin, and seeped through the tissues in a fine network of blood vessels. Veins and arteries were recognized as somewhat different in structure but their special purposes were not recognized. The venous side of the system was considered to be the more important. Thus the blood, continuously renewed by the liver and just as continuously consumed by the body, containing the three essential spirits formed by the three most important organs in the body, the liver, brain, and heart, and activated by the all-pervasive Pneuma, sustained animal life. This, in essence, is the Galenic concept of the cardiovascular system. It had served well for over fourteen hundred years. It answered all questions and, it was so comfortable.

But why do men and women eventually appear who dare to say what they think, describe what they see, and fly in the face of established authority? Where, out of the morass of the early days of the Renaissance did Vesalius come from, and why? Why did Harvey, in so many ways the very antithesis of Vesalius, appear with the same single-mindedness, to pursue an independent course, though fearing censure, working in secret, and delaying publication out of reticence and modesty? Where did Harvey come from, and why? Why a Newton, a Copernicus, Kepler, or Boyle?

Leonardo da Vinci, who seems to have investigated mainly for his own satisfaction, never bringing his work to a clear, ultimate conclusion, and never publishing anything, showed in his drawings a good representation of the gross anatomy of the human heart and an appreciation of the probable function of the cardiac valves. With Berengario we can be sure that his published works were based on his personal observation of human dissection. Though a Galenist, he stated as early as 1521 that he strongly doubted the presence of pores in the cardiac septum, for the simple reason that he didn't see any. When 
Vesalius, like a comet, flashed upon the scene in 1543 with De Humani Corporis Fabrica Libri Septem, Galenic principles were never thereafter on a firm foundation. A new method of dissection, experimentation, and teaching had been established, though to be sure these iconoclastic teachings were by no means everywhere accepted. Vesalius had been educated totally in Galenic principles and he never did completely overcome his obeisance to the great master. However, in the 1555 edition of the Fabrica he did rather reluctantly state that he found no holes in the cardiac septum for the passage of blood. His basically accurate and complete account of human anatomy created a secure framework for the physiology that was to follow, and it was the result of his own intense, personal study.

From ancient times there had always been an interest in and a confused explanation of the pulmonary circulation. It has been thought by some historians that Michael Servetus, the Spanish theologian-philosopher-mathematician and superficially trained physician, may have obtained his essentially accurate description of the pulmonary circulation, as he described it in Christianismi Restitutio (1553), from the Syrian physician Ibn-al-Nafis (ca. 1289). ${ }^{1}$ Most likely, however, this suspicion is not true. Servetus' description of the flow of blood from the right to the left side of the heart through the lungs was basically correct, though he did not recognize the function of the lungs. It is strange that he should even have written this little tract on physiology, but it is the main thing by which he is remembered. Immediately upon publication the Church declared him a heretic, the book blasphemous, as many copies of the book as possible were collected, and they and Servetus were burned at the stake at Geneva in 1553. Only three copies of the book are known to have survived. Servetus should have contented himself with essays on The Syrups, and left the circulation alone.

${ }^{1}$ Owsei Temkin, The Double Face of Janus and Other Essays in the History of Medicine (Baltimore: Johns Hopkins University Press, 1977), p. 284, and Geoffrey Keynes, The Life of William Harvey (Oxford: Clarendon Press, 1966), p. 170. 
Andreas Cesalpino, who occupied the chair of anatomy at the University of Pisa from 1544 to 1549, wrote of the heart's action and the lesser circulation in his Peripateticarum Quaestionum (1571), a posthumous publication which showed little originality and nothing based on actual experimentation. The fact that he borrowed from Colombo may or not be true, but it is unlikely that Harvey, who knew of the work, was in any way influenced by it. Realdo Colombo, who followed Vesalius in anatomy at Padua, published De re Anatomica in 1559. It was an excellent text, drawn mostly from Vesalius, and without illustrations. His description of the pulmonary circulation was the most accurate to date, and he noted that the blood returning to the heart via the pulmonary vein was of a lighter, brighter color than the blood in the pulmonary artery. But Fabricius ab Aquapendente, as Harvey's teacher, greatly influenced Harvey's later work by his studies on the valves of the veins, as expressed in his work De Venerum Ostiolis (1603). Training in the intellectually-charged atmosphere of the international student body at Padua, Harvey could not but be intrigued by various problems of human anatomy and physiology, particularly that of the venous valves and how they prevented the return of blood to the periphery of the body. Of all the teachers of anatomy and physiology with the work of whom Harvey was acquainted, and with the large amount of medical literature available, the greatest influence leading Harvey to the creation of De Motu Cordis was his association with Fabricius. Yet Harvey could not agree with Fabricius on many points, particularly the function of respiration. Though Fabricius accurately described the valves in the veins, he did not understand their purpose; that was for Harvey to demonstrate later.

William Harvey was born on April 1, 1578, in the English county of Kent at Folkestone. His father, Thomas Harvey, was a prosperous merchant who served as mayor of Folkestone later in his career. William was the oldest child of his father's second marriage and had six brothers and two sisters. When he was twenty-six he married Elizabeth Browne, daughter of Sir Lancelot Browne, physician to the king. Elizabeth remains a 


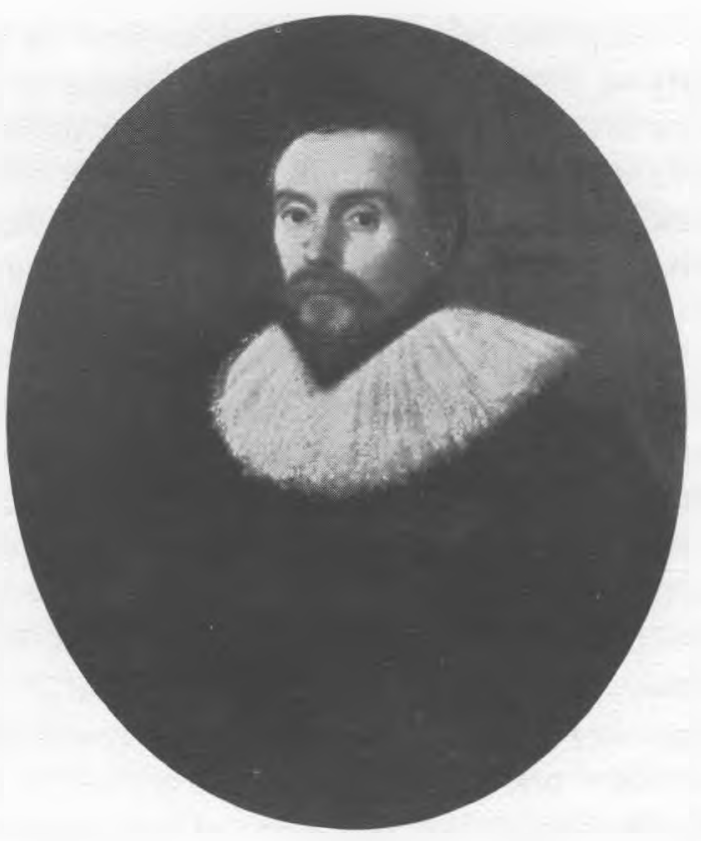

Portrait of William Harvey at about age 45 .

shadowy figure, was never mentioned in any of Harvey's published works, they had no children, and she died some ten years before William, who died on June 3, 1657.

He was educated at King's School in Canterbury, which he entered in 1588. He continued his studies at Gonville and Caius College, Cambridge, where he graduated as Bachelor of Arts in 1597. The following year Harvey went to Padua to study medicine and graduated in 1602 with his Doctor of Medicine. In the same year he returned to England and was incorporated as a Doctor of Medicine of the University of Cambridge. In 1604 he became a member of the College of Physicians and was made a Fellow in 1607. By 1607 he had also been made a Fellow of the Royal Society, an honor coming unusually soon for a young man, and particularly one trained abroad. But his peers recognized in Harvey a mind exceptionally bright and gifted, and thoroughly trained in the Galenic principles to which the Royal Society so faithfully adhered. 
Harvey's professional life as a physician was largely associated with St. Bartholomew's Hospital, the College of Physicians of London, and the royal court where he served as physician to the King. He was appointed physician to St. Bartholomew's in 1609 and was the only physician on the staff, which also included three surgeons and an apothecary. His duties included attendance at the hospital at least once a week and examination and prescription of therapy for patients.

While he was physician to St. Bartholomew's, Harvey was a capable and competent administrator and recommended a number of changes to improve management of the hospital. He also took care to maintain the superior status of the physician over the surgeon and decreed "that the Chirurgions, in all difficult cases or where inward physic may be necessary, shall consult with the Doctor, at the times he sitteth once in the week and then ... relate to the Doctor what he conceiveth of the cure and what he hath done therein." 2

Harvey made notes on many of the diseases he encountered and also performed a large number of autopsies, including some on his own relatives. The conditions he described include enlargement of the spleen in ague, constrictive pericarditis, and liver diseases including abscess, cancer, hydatid disease, and amyloidosis. In medical practice Harvey adhered largely to the common practices of his era. He espoused bloodletting as "foremost among all the general remedial means" and also followed the polypharmaceutical practices of the day which dictated the dispensing of medications containing numerous ingredients, few of which were active. ${ }^{3}$

Although busy with his medical responsibilities, Harvey also found time to quietly work in his small laboratory, two rooms attached to his home. There, with the seeds of wonder and curiosity planted in his mind during his years at Padua, together with his observations at his anatomy demonstrations, he fulfilled the urge to answer for himself the recurring

${ }^{2}$ D'Arcy Power, William Harvey (London: T.F. Unwin, 1897), pp. 100-101.

${ }^{3}$ Herbert Ritchie Spencer, William Harvey, Obstetric Physician and Gynaecologist (London: Harrison, 1921), p. 33. 
questions which conflicted with established beliefs concerning the motion of the heart and blood in animals. Quietly, privately, almost secretly, he carried on experiments and recorded observations on the development, growth, and action of the cardiovascular system in all forms of animal life, from insects and worms, through various species amphibian and avian, to warm-blooded animals such as cats and dogs. Much, if not most, of this study was done with vivisection. His role as teacher of anatomy allowed repeated close observation of the human body. He performed public anatomies, conducted autopsies, and studied the living human subject as well. Brought up in the Galenic concept of biology, he taught these concepts, for it was required by the Royal Society that he do so. Nevertheless, Harvey early had private doubts, if not outright denial, of much of Galen's rules, particularly those concerning the cardiovascular system. But it was the ill-advised person who ever expressed any such doubts in public.

Harvey was appointed Physician Extraordinary to King James I in 1618. By this time he was also physician to many of England's leading citizens as well as a popular consultant. He was ordered by Charles I, who became King in 1625, to accompany the Duke of Lennox on a diplomatic visit to the Continent in 1629 and in 1631 Harvey was appointed Physician in Ordinary to Charles. Harvey's responsibilities at the royal court became so time-consuming that a deputy physician was appointed to assist him at the hospital in 1631. Although he was still able to occasionally fulfill his duties at the hospital, he lost his appointment because of his royalist sympathies once the Civil War began in 1642. It was fortunate for Harvey that Charles was an avid huntsman and allowed him to dissect the spoils of the hunt because it gave Harvey many opportunities to study embryonic development, especially of deer, information he later incorporated in De Generatione Animalium (1651).

When the Civil War started in 1642 Harvey accompanied the King when he left London and was with the royal court at Oxford, which was Charles' headquarters for the next four years. In 1642 he was incorporated as a Doctor of Medicine at 
Oxford and in 1645 he was appointed Warden of Merton College. Harvey was in the post only a short time because it reverted to a parliamentary supporter the following year when Oxford fell to the king's enemies and Harvey returned to London. After that he was largely inactive in public life, with the exception of the affairs of the College of Physicians, in which he continued to take an active interest for the rest of his life.

Harvey's greatest work was directly associated with London's College of Physicians, which he never served as president, but was censor in 1613,1625, and 1629, and treasurer in 1628. His royalist political sympathies would have kept him from the presidency during or immediately after the Civil War and, when unanimously chosen as president in 1654, he declined on the grounds of age and infirmity.

Reticent, shy of publicity, preferring to work alone, Harvey was above all else an honest man, and he wrote down his observations of experiments exactly as he saw them. He had the gift of being able to throw out all distracting, irrelevant questions and intently to pursue one problem at a time, slowly building his store of evidence. Using dissection at all stages of animal development; watching the blood pour from sectioned arteries and veins; noting the effect of ligation on arteries and veins; using a bellows to inflate the lungs and simulate respiration in a decapitated dog; watching the living, pulsating heart in various animals; dissecting veins and watching the direction of the blood flow as opposed to the arterial flow; watching the heart and peripheral vessels in the expiring, hemorrhaging animal; repeatedly observing the muscular activity of systole and diastole; considering the particularly efficient occlusive action of the cardiac valves, and with many other studies, Harvey became familiar with phenomena never before observed. He was particularly impressed by the quantity of blood, and did not believe that such a large volume of blood that he computed to be present in the average human adult could be maintained through renewal by the liver in an individual who 
had been given no food or drink for twenty-four hours. He did not think it possible for the liver to produce such a quantity of blood, or that the venous side of the vascular system was more important than the arterial. By simple mathematical deduction, considering that at each thrust the left heart in systole discharged approximately three drachma of blood into the aorta, at seventy-two times a minute, at sixty times that for an hour, and at twenty-four times that for one day, it was preposterous to believe that such a large volume was created, consumed by the body, and recreated continuously. Such a volume of blood would weigh far more than the body itself. " "Ebb and flow" was not what sectioned vessels showed. An animal quickly exsanguinated and died with opened, spurting arteries. The fact had to be that the same blood was used over and over, that it passed rapidly through the body from the arterial to the venous system, and to accomplish this it had to be in constant motion as in a circle. It had to circulate. The heart was a pump.

Harvey looked for pores in the cardiac septum and found none. The fetal ductus arteriosus and foramen ovale were recognized for what they really were. He noted that the pulmonary artery and vein were of equal size, indicating that the same amount of blood that entered the lungs came out of them, and that that volume of blood was much too large simply for the nourishment of the pulmonary parenchyma. He postulated a "fine connection" between the veins and arteries in the lungs, noting, as Colombo had done, that the blood in the pulmonary vein was brighter and redder than in the pulmonary artery, as if "refreshed by new spirit." He saw no evidence of sooty vapors in the blood nor of air in the blood of the pulmonary vein. He demonstrated that cardiac pulsation and respiration were separate functions. He proved that the arterial pulsation was due to the cardiac thrust, and though he had no tools with which to prove his hypothesis, he believed that the blood, moving peripherally through the arteries,

${ }^{4}$ The average adult human body volume of blood is about $7 \%$ of the body weight, or approximately 11 pints, and each ventricle is capable of containing about 3 ounces of blood. 
entered the venous system through minute connections in the tissues, and returned steadily toward the right heart through the veins, being kept on course by the venous valves.

The Lumleian Lectureship, founded in 1582 at Oxford by Lord John Lumley, was for the purpose of furthering the knowledge of surgery. Only a Fellow of the Society was allowed to deliver the annual series of lectures, and to be chosen as a lecturer was no small honor. Harvey was chosen to give the lectures in 1616, and the bodies of two convicted felons, whose hanging was conveniently timed, were used for the anatomical demonstrations at the lectures on April 16, 17, 18. He had approximately two weeks in which to prepare his three lectures, entitling the manuscript: "Lectures on the Whole of Anatomy by me William Harvey, Doctor of London, Professor of Anatomy and Surgery. Anno Domini 1616, aged 37, delivered on April 16, 17, 18 on the male and female body." These we now know as the famous lecture notes, the Praelectiones Anatomicae.

It might be supposed that having already done so much experimentation on the circulation of the blood by 1616, the Praelectiones would somewhere state Harvey's final concept of the vascular system. But this is not so. Even if at that time he had made his final conclusions concerning the circulation, he could not have safely expressed his opinions publicly, though he did discuss his work in private with certain friends. There is evidence that it was not until 1627 that he clearly and finally stated his conclusions as they appear in De Motu Cordis. In fact, the Praelectiones Anatomicae of 1616, greatly dependent in content on Casper Bauhin's anatomical text Theatrum Anatomicum (1605), did not advance much further in new material on the heart and blood than could already be found in the work of Realdo Colombo. But during "those nine years," from 1616 to 1627, Harvey obviously collected a substantive amount of new data, to the point that he felt publication might be in order, though he feared that step.

From 1616 onward Harvey's private studies, his direct and logical experiments on the motion of the heart and blood, and 
his belief that what he actually saw was true contrary to previous hypotheses, all eventually found place in one form or another in his public lectures, his anatomies, and the Praelectiones. All this, by 1627 gathered into a compact mass which in large part had been ready for nine years, tumbled forth at last as De Motu Cordis in 1628. After that, medical thought was never to be the same. Harvey never overcame some of his Galenic concepts, and at heart he remained an Aristotilean. De Motu Cordis contains many references to both Aristotle and Galen, but it does not concern itself with the role of special Spirits and the Pneuma. De Motu Cordis confirmed a new, logical thesis in the face of ridicule and outcry, but the movement of the heart and blood had been so simply and directly stated that that attractive and long-troubling subject could at last be understood in simple terms.

De Motu Cordis et Sanguinis in Animalibus, a very small book, barely more than a pamphlet, opens with a short dedication to King James I. In a letter to his friend, Doctor Argent, and in the Prooemium, Harvey states his reasons for at last making public his radical hypothesis. Not, he insists, for personal glory, but rather was it done to correct errors which had gone unchallenged for centuries. This shoddy, cheaply made little book of only sixty-eight pages of type is written in lean, sparse, uncomplicated prose, and with such little elaboration that following such a bare-bones account is not easy. It requires slow, thoughtful consideration. The last three chapters of the book wander somewhat from the main theme, but the fourteenth chapter, which actually ends his argument, summarizes the work so succinctly that it deserves recording here:

\section{"Chapter Fourteen}

Conclusion of my description of the circuit of the blood. May I now be permitted to summarize my view about the circuit of the blood and make it generally known!

Since calculations and visual demonstrations have confirmed all my suppositions, to wit, that the blood is passed through the heart and the lungs by the pulsations of the ventricles, is forcibly ejected to all parts of the body, 


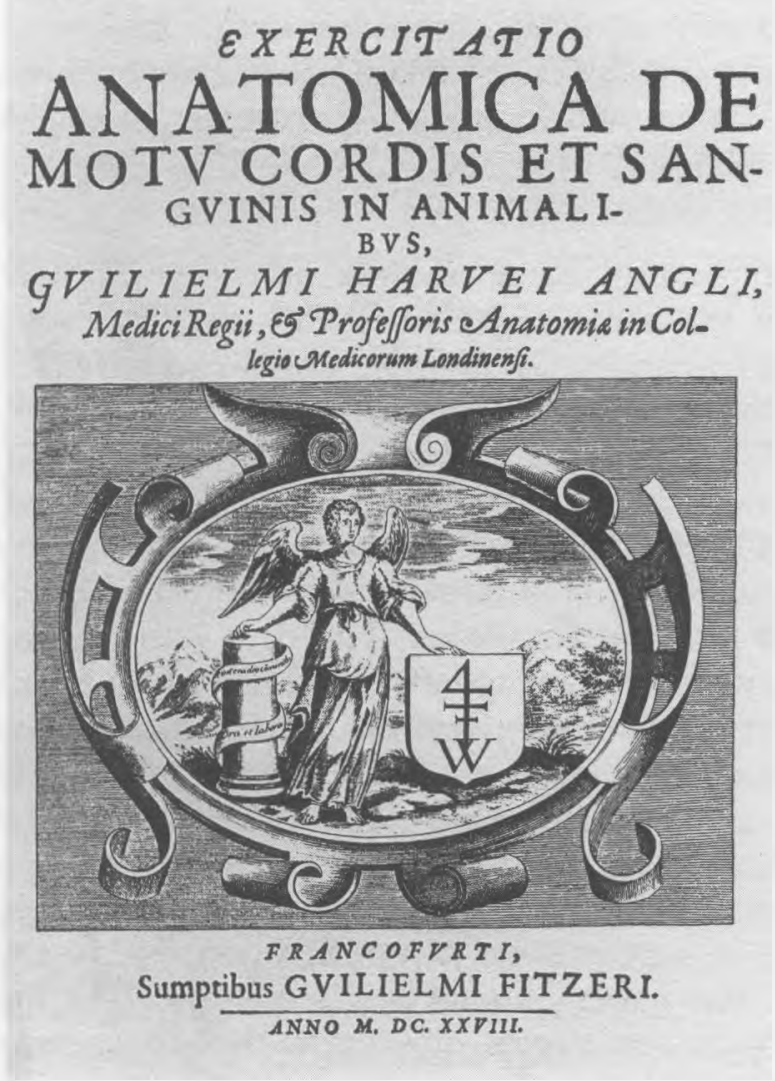

Title page from The University of Iowa Libraries copy of Du Motu Cordis.

therein steals into the veins and porosities of the flesh, flows back everywhere through those very veins from the circumference to the centre, from small veins into larger ones, and thence comes at last into the vena cava and the auricle of the heart; all this, too, in such amount and with such a large flux and reflux - from the heart out to the periphery, and back from the periphery to the heart-that it cannot be supplied by the ingesta, and is also much greater in bulk than would suffice for nutrition. 
I am obliged to conclude that in animals the blood is driven round in a circuit with an unceasing, circular sort of movement, that this is an activity or function of the heart which it carries out by virtue of its pulsation, and that in sum it constitutes the sole reason for that heart's pulsatile movement." 5

That unquestionably is a clear statement. But a modern student of William Harvey's life and work has stated, "The proper understanding of De Motu Cordis can only be had from the knowledge of the whole of Harvey's thoughts." 6

Harvey's caution and reticence about publishing his work is a well-known story. He feared ostracism by his contemporaries and loss of medical practice, and on both accounts he was right. But eventually he was convinced by a friend, the strange, somewhat mystical Dr. Robert Fludd, a Rosicrucian, to have the book published. A young Englishman, James Fitzer in Frankfort, was chosen for a printer. Fitzer was the son-in-law of Johann Theodore de Bry, who had been the printer of Fludd's numerous publications. Fitzer was a poor choice. He produced a cheaply made book, printed with poor type on poor paper, with only a few copies on paper of lasting quality. Most existing copies are in a poor state of preservation due to the inferior quality of the paper and its acidic content. It is not known exactly how many copies now exist, probably approximately seventy, most of these being in institutions. If the manuscript reached Fitzer in Harvey's handwriting, which it probably did, Fitzer must have had a difficult task in deciphering the author's execrable script. It is possibly because of this that when the first copies were sent to England for Harvey's review that he found 126 errors, and sent back the list with the request that a proper errata list be added to the remainder of the issue. Many more errors were found by later editions. Many existing copies of $D e$ Motu Cordis do not contain the errata page. It may be, too, that

${ }^{5}$ William Harvey, Movement of the Heart and Blood in Animals, An Anatomical Essay. (Springfield, IL, 1957), p. 87.

${ }^{6}$ Gweneth Whitteridge, William Harvey and the Circulation of the Blood (London: Macdonald, 1971), p. 144. 
the young and inexperienced printer did not realize the importance of the work entrusted to him and that he thought it warranted only indifferent treatment. Fitzer's judgment remains one of the sad facts of medical history. ${ }^{7}$

The book was distributed fairly widely both in Britain and on the Continent. It was met, to put it in modern terms, with mixed reviews. The overwhelming judgment was that the whole thing was simply unthinkable nonsense. The majority of British physicians, some of the brightest minds, condemned the book soundly. The first vituperative blast came in 1630 from James Primrose, a young physician of Hull, who had been a pupil of the French anatomist-physician, Jean Riolan. A Venetian physician, Emilius Parisanus, also savagely refuted Harvey in 1635 , but he was silenced by a reply from Sir George Ent, long a friend of Harvey, and the same George Ent who urged Harvey to publish his work De Generatione Animalium in 1651. Robert Fludd likewise staunchly supported Harvey and answered many of his critics. On the Continent the book was met with utter contempt by most of the medical community, among them the renowned Caspar Hoffman, with whom Harvey later had a considerable correspondence. Jean Riolan was Europe's loudest and most acrimonious critic, and his criticism bore weight because he was a fine and much respected anatomist, though he was no intellectual match for Harvey. His criticisms finally goaded Harvey at last to publish in 1649 a small book of two "letters" to Riolan in which Riolan was answered in polite, concise terms, with an occasional slight put-down added. René Descartes was Harvey's strongest supporter in Europe. He first saw De Motu Cordis in 1632 after he had already stated in Tractatus de Homini, then in preparation, essentially the same hypothesis as Harvey concerning the vascular system.

${ }^{7}$ It is not known how many copies of De Motu Cordis were printed in 1628, but the number was probably limited. Keynes states: "The publication of the book was announced in the Ostermesskatalog for 1628 and it was issued in the autumn of that year at the price of 6 schilling 2 pfennig" (Geoffrey Keynes, The life of William Harvey. Oxford, 1966). 

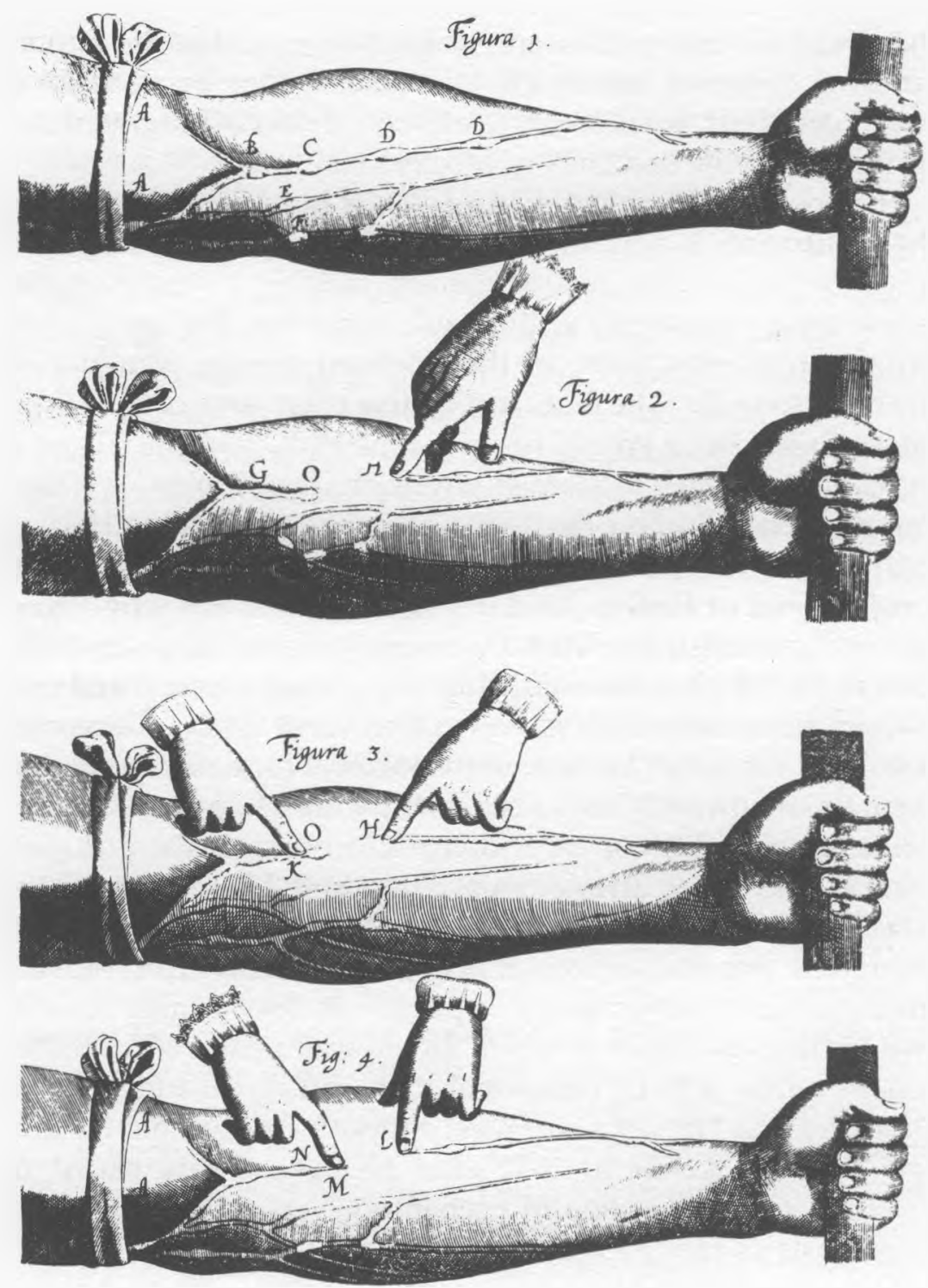

These figures, demonstrating the valves of the veins and direction of the venous blood flow, are the only illustration in any edition of De Motu Cordis. 
Eventually the support of accumulated physiological experimentation and discovery, such as that of the discovery of the capillaries by Malpighi in 1661, led to a general, if not complete, acceptance of Harvey's thesis. He regained his practice, stayed in the King's service, traveled, continued to collect data on projected but never published work on the action of the muscles and the physiology of insects, and at last completed his manuscript for De Generatione Animalium, published in London and Rotterdam in 1651. He lived to see his main life work vindicated, bringing him at last some satisfaction. Yet he had suffered the loss of his laboratory, many records and manuscripts, and other property at the hands of Cromwell's ruffians; he mourned the loss of his wife; and in his last years he suffered greatly from gout of the feet. Portraits of Harvey in old age do not depict a happy man.

It is impossible to review the lives of the great anatomists and physiologists of the sixteenth and seventeenth centuries and not compare Vesalius and Harvey. Poles apart in their personalities, together they broke the bonds of Galen. They instituted the new concept of performing dissections and experiments with their own hands, and of teaching directly from the animal or human subject. They both dared to record and publish what they saw. They both suffered the anguish of unwarranted criticism. Vesalius established forever anatomy as the central pivot of biological science. Harvey, breaking with the ancients who had been more interested in the philosophical why than the factual how, brought to conclusion what is doubtless the greatest contribution to physiology of all time. De Motu Cordis is not remembered only by the revealed facts, but also and especially by the method with which those facts were made known. 